\title{
GOMMENTS
}

\section{COMMUNITY, HOME, AND THE RESIDENTIAL TENANT}

\section{Blair Cameron Stone ${ }^{\dagger}$}

The law governing the relationship between landlords and tenants-a set of common law rules that remained relatively constant for several centuries ${ }^{1}$ - has undergone substantial judicial and legislative revision over the last two decades. ${ }^{2}$ Nevertheless, the tenant today is still regarded as the temporary user of a dwelling belonging to her landlord. The landlord may select her tenants on whatever basis she pleases (within the confines of civil rights statutes), ${ }^{3}$ control her tenants' use of the leased premises," and oust her tenants "for any reason or no reason at all" at the end of the lease term. ${ }^{5}$

In this Comment, I take the view that traditional landlord-tenant law permits the acquisition of shelter but denies the acquisition of a home. The home is the locus from which the individual establishes her connection to the community. To the extent that the tenant is unable to select her home, to use it in ways that reflect and express her personality, and to feel secure in her tenure, her ability to be a member of her community is curtailed. If we value community, our law should not hinder participation in the community by any group, including tenants. In turn, the allocation of property rights recognized by our legal system should reflect the fact of our interdependence, that is, our need for community.

Perhaps a warning is in order: this is not a Comment on landlordtenant law. I do not present an exhaustive and detailed picture of what

† A.B. 1982, University of California, Los Angeles; J.D. Candidate 1986, University of Pennsylvania.

I See R. Schoshinski, American LaW of LANDlord AND TENANT at v (1980 \& Supp. 1985).

${ }^{2}$ See id. See generally Berger, The New Residential Tenancy Law-Are Landlords Public Utilities?, 60 NEB. L. REv. 707 (1981); Glendon, The Transformation of American Landlord-Tenant Law, 23 B.C.L. REv. 503 (1982); Rabin, The Revolution in Residential Landlord-Tenant Law: Causes and Consequences, 69 CoRNELL L. REv. 517 (1984).

3 See infra notes 68-76 and accompanying text.

- See infra notes 77-80 and accompanying text.

S See infra notes 41-43 and accompanying text. 
the law is. Rather, I examine certain incidents of the law in order to describe the condition of being a tenant and to develop proposals for changing the law governing the tenant's status.

In form this Comment moves from the general to the particular, from the theoretical to the practical. Part I offers a theory of community and argues that individualistic notions that deny community its due as a constitutive element of the individual deny a part of what it is to be human. Part II examines the concept of home within the context of community and argues that we must have a home in a community in order to be a part of that community. Part III discusses the restrictions and lack of security under which tenancy exists, arguing that these conditions deprive tenants of a true home and therefore of a true place in the community. Finally, Part IV analyzes the elements of ownership in a rental unit and describes how the rights attached to those elements could be allocated in a legal system that encouraged full community membership for tenants. The suggested division of rights grows out of the idea that one's rights in property can and should be determined by the function served by that property.

\section{A Theory of Community}

Few would argue with the assertion that the human species is a social species, ${ }^{6}$ that sociality is a necessity of human existence-in short, that "[t]here is nothing natural about human life in a state of nature." There is, however, much disagreement over the relationship between the individual and the community. There are three possible ways to view this relationship: (1) the individual claims priority over the community; (2) neither individual nor community can claim priority over the other; and (3) the community claims priority over the individual. The labels that seem to fit these possibilities are individualism,

B See, e.g., V. McCabe, Examples of Biological and Social Theory with Respect to Differences 7-8 (1984) [unpublished manuscript on file with the University of Pennsylvania Law Review]:

The biological constraint most at odds with the notion of individuality is the fact that human beings were social animals before they were "rational" animals.

Fossil remains clearly show that our species [predecessors] Australopithecus africanus and Homo habilis lived in groups ... . Because we are biosocial animals, our biologically rooted sociality precedes our "free choices" and restricts the possible range such choices can take. . . .

... [F]ree choice may involve some leeway in the kind of social structures [we] can construct, but [will not allow us to rationalize ourselves] out of sociality ....

7 Grey, Property and Need: The Welfare State and Theories of Distributive Justice, 28 Stan. L. REv. 877, 891 (1976). 
communitarianism, and collectivism, respectively. Because the dominant American ethic is individualism, and I am proposing a communitarian ethic as an alternative, this discussion will be confined to a comparison of the two.

Individualism, the consciousness of which is embodied in political liberalism, ${ }^{8}$ holds that "I am what I myself choose to be. I can always, if $I$ wish to, put in question what are taken to be the merely contingent social features of my existence. . . . [T] he self is [viewed as] detachable from its social and historical roles and statuses." ual is self-determining and can extricate herself from social constraints by an act of sheer will, the social union becomes merely the instrument of individual ends. ${ }^{10}$ The community is good only to the extent that it furthers the self-interest of "radically separate individuals who are fated to struggle against one another even when their antagonism is tempered by reciprocal forbearance and collaboration."11

The ethic of individualism, while admitting the necessity of sociality, does so only with reluctance. Because social cooperation depends on a shared vision of social ends, it stands in constant tension with the priority of the individual, whose freedom to choose her own ends must remain inviolate. ${ }^{12}$ The community is thus "a second-order and derived

8 See R. Unger, KNowledge and Politics 155 (1975). The consciousness of individualism extends, of course, beyond our political theory; indeed, "[i]ndividualism lies at the very core of American culture." R. BELlah, R. MAdsen, W. Sullivan, A. Swidler \& S. Tipton, HaBirs of THE HEaRT: Individualism and CoMmitment IN AMERICAN LIFE 142 (1985) [hereinafter cited as R. BELLAH]. Habits of the Heart is, in part, a fascinating sociological study of the question "whether an individualism in which the self has become the main form of reality can really be sustained." Id. at 143. In response, the authors suggest that "perhaps only the civic and biblical forms of individualism - forms that see the individual in relation to a larger whole, a community and a tradition-are capable of sustaining genuine individuality and nurturing both public and private life." Id.

- A. Macintyre, After Virtue 220-21 (2d ed. 1984).

10 See M. SANDel, Liberalism aNd The Limits Of JuStice 148 (1982). Sandel argues that John Rawls' attempt to moderate the instrumental view of community by allowing partial internalization of the community by the individual fails to support his argument that the assets of individuals should be shared with society; only if society is viewed as constitutive of the individual can assets be held in common or fates be shared. See id. at 147-52 (discussing J. Rawls, A Theory OF Justice 520-29 (1971)).

11 . UNGER, supra note 8, at 155 ; see also R. BELLAH, supra note 8, at 143 :

In seventeenth-century England, a radical philosophical defense of individual rights emerged .... . [I]t consciously started with the biological individual in a "state of nature" and derived a social order from the actions of such individuals ... . John Locke is the key figure and one enormously influential in America. The essence of the Lockean position is an almost ontological individualism. The individual is prior to society, which comes into existence only through the voluntary contract of individuals trying to maximize their own self-interest.

${ }^{12}$ See R. UNGER, supra note 8, at 155 . 
phenomenon that is primarily regarded as restricting the individual's autonomy and as warping [her] deepest nature."13

This, to be sure, is the picture of individualism painted by its critics, but the conclusion that the first-order phenomenon is the individual is logically unavoidable as soon as the individual is identified as the sole and proper source of her own being and destiny. If the good for the individual consists of self-determination, it cannot consist of social determination except to the extent that the individual will and the social will coincide, and to the extent that they do coincide, one's individuated status is threatened. ${ }^{14}$

But what if self-determination in the individualistic sense is itself an impossibility? What if "the social and communal aspects of human life are the necessary environment for the flourishing of essential human capacities"?15 What if we "are embedded in language, history, and culture, which are social creations, [so that] there can be no such thing as a person without society" ${ }^{16}$ From these questions the communitarian ethic is derived. Is it not true that

we are never more (and sometimes less) than the co-authors of our own narratives[?] Only in fantasy do we live what story we please. In life . . . we are always under certain constraints. We enter upon a stage which we did not design and we find ourselves part of an action that was not of our making. Each of us being a main character in his own drama plays subordinate parts in the dramas of others, and each drama constrains the others. ${ }^{17}$

If "there can be no person without society," and because there can be no society without people, it makes no sense to say that one must come before the other, physically or metaphysically. Any attempt at prioritization leads to a conundrum analogous to that of the chicken and the egg.

13 J. Friedmann, The Good Society 84 (1979).

14 See R. UNGER, supra note 8, at 215 ("[T]he more intimate the similarity of experience and reflection among individuals, the less of a basis does individual identity seem to have.").

${ }_{18}$ Grey, supra note 7 , at 891 n. 39.

18 Radin, Property and Personhood, 34 Stan. L. Rev. 957, 965 (1982) (footnote omitted). As Hannah Arendt pointed out, "[T]he Romans . . . used the words 'to live' and 'to be among men' (inter homines esse) or 'to die' and 'to cease to be among men' (inter homines esse desinere) as synonyms." H. ARENDT, THE Human Condirion 7 8 (1958). Arendt herself argues that "[n]o human life, not even the life of the hermit in nature's wilderness, is possible without a world which directly or indirectly testifies to the presence of other human beings." Id. at 22 .

17 A. MACINTYRE, supra note 9 , at 213. 
While denying the premises of individualism, communitarianism does not deny individuality. ${ }^{18}$ Each member of the species is unique in both her physical embodiment and her consciousness, ${ }^{19}$ but she is not the sole author of her uniqueness. Unless we allow for the interdependence of individuality and sociality, a satisfactory explanation of what it means to be human will elude us:

It is one of the requirements of personality that one be recognized by others as a person. ...

... [T]he self is defined by the totality of its relations with other . . . selves. . . . More precisely, we are our relations; the way in which others conceive of those relations is one of their determinants, and therefore one of the determinants of our own selfhood. If one could imagine a situation in which no one treated a person or had ever treated him as a human being with a self, then in that situation he would have no self. ${ }^{20}$

A human being raised by wolves would be human in appearance but not in consciousness. ${ }^{21}$ Not only would she lack the aspect of selfhood that is defined by relations with other humans (her relational identity would be lupine), but her consciousness could not be formulated or expressed in human terms. In short, the baggage with which we arrive on this earth will not carry us very far. Human consciousness is informed by the language, culture, and tradition of the community, ${ }^{22}$ and the

18 See R. UNGER, supra note 8, at 213 ("The attribute of the self by virtue of which it must always be a particular self, distinct from other selves, is called individuality.").

10 See H. ARENDT, supra note 16, at 8 ("Plurality is the condition of human action because we are all the same, that is, human, in such a way that nobody is ever the same as anyone else who ever lived, lives, or will live.").

${ }^{20} \mathrm{R}$. UNGER, supra note 8 , at 216.

21 See L. MALSON, WOLF ChILDREN 12 (1972) ("TT]he search for human nature among 'wild' children has always proved fruitless precisely because human nature can appear only when human existence has entered the social context.").

To Hannah Arendt, activities carried on outside the realm of social relations were not "human" activities:

All human activities are conditioned by the fact that men live together . . . . The activity of labor does not need the presence of others, though a being laboring in complete solitude would not be human but an animal laborans . . . Man working and fabricating and building a world inhabited only by himself would still be a fabricator, though not homo faber: he would have lost his specifically human quality and, rather, be a god ... a divine demiurge as Plato described him in one of his myths.

H. ARENDT, supra note 16, at 22 .

${ }_{22}$ See Grey, supra note 7, at 895. 
"medium through which consciousness expresses itself is made up of the symbols of culture, . . . [which] are irreducibly social.".23 A theory of community that satisfies the communitarian ontology, as contrasted with that of individualism, has been characterized as one that

would describe not just a feeling but a mode of self-understanding partly constitutive of the agent's identity. ... [This view holds that members of society] conceive their identity . . . as defined to some extent by the community of which they are a part. . . . [C]ommunity describes not just what they have as fellow citizens but also what they are .... In contrast to the [individualistic] conceptions of community, we might describe this strong view as the constitutive conception. ${ }^{24}$

The communitarian ethic, as presented here, does not swallow the individual. It is distinguished from liberal individualism in recognizing that the individual cannot be disaggregated from her community, but it does not pretend to solve what Duncan Kennedy has called "the fundamental contradiction" between the need for autonomy and the need for community. ${ }^{25}$ Liberal individualism, by denying the constitutive aspect of community, enables one to "deny the fundamental contradiction."26 Only by recognizing the validity of both sides of the contradiction can we confront the problems of social organization with a clear vision. If the individual deprived of community is deprived of an element of what it means to be human, and if the good society is one that creates the necessary conditions for individuals to develop their human capacities, then the degree to which a society affords its members participation in community is one measure of its success.

In the next part of the Comment, I develop the connection between community in this abstract sense and community in a more concrete sense: community as the place we make our home. While this part has spoken primarily through the voices of philosophers and theorists, in the next we shall hear from the planners of cities and housing as well.

23 R. UNGER, supra note 8, at 215.

$24 \mathrm{M}$. SANDEL, supra note 10 , at 150 .

2s See Kennedy, The Structure of Blackstone's Commentaries, 28 Buffalo L. REv. 205, 211-13 (1979). But see Gabel \& Kennedy, Roll Over Beethoven, 36 STaN. L. REv. 1, 15-16 (1984) ("I renounce the fundamental contradiction. I recant it, and I also recant the whole idea of individualism and altruism, and the idea of legal consciousness ... . I mean these things are absolutely classic examples of 'philosophical' abstractions which you can manipulate into little structures.").

${ }^{26}$ Kennedy, supra note 25, at 217. 


\section{Home IN Community}

The word "community" can describe groups having distinct features that unite the members in some way. Thus, we can speak of the gay community, the Irish Catholic community, or the stamp-collecting community. Communities defined solely by traits, beliefs, or interests are important units of social organization, but they do not reduce the need for a community that surrounds one's home, a community based on physical proximity. Community in this sense depends on "frequent social interaction among persons who live... close to one another .... They 'connect' through sharing a common place or neighborhood, developing a feeling that can transcend their individual differences and forge them into a larger common sphere of loyalty and support."27 If we do not know and are not known by the people among whom we live, our relationships will be characterized by anomie and alienation, "insecurity and hostility rather than ... cohesiveness and cooperation."28 Certainly one can survive such conditions, for they describe the lives many of us lead. Nevertheless, a life of anomie is a life deprived of context:

When people . . . say "my neighborhood," it usually means they have found a place to live where they feel some human sense of belonging, some human sense of being part of a society ... rather than just being in a society ... . But, then, people can just as easily say simply "where I live," as though it is merely a rest stop on a road full of such stops, with each one merging into the next so hazily that it takes handfuls of old bills to even remember where you've been. Neighborhoods are memorable. A jumble of "places" where you've lived is not. ${ }^{29}$

Being part of a society as opposed to merely being in a society is memorable because of the constitutive nature of the relationship between the individual and the community of which she is a part. We remember that which is a part of ourselves:

[P]eople develop their world view and absorb their basic val-

27 N. Newmark \& P. Thompson, Self, Space, and Shelter: An Introduction to Housing 21 (1977). But see T. Bender, Community and Social Change IN AMERICA 6 (1978) (arguing that "[c]ommunity [is] defined better as an experience than as a place" and that "[t]erritorially based interaction represents only one pattern of community . . . A preoccupation with territory thus ultimately confuses our understanding of community.").

28 N. NewmaRK \& P. Thompson, supra note 27 , at 21.

29 D. MORRIS \& K. Hess, NeIghbORHOOD POWER 1 (1975). 
ues from [their] society or community . . . ; they form their deepest emotional attachment to persons, places and institutions; they learn as part of themselves a language, a culture and a tradition.

... It is true that for many persons these attachments do not form ... . But [this is] generally and appropriately regarded as evidence of social failure, the failure of a society to provide a satisfying and harmonious setting for human life and growth. When a society successfully achieves a sense of community, most of its members can leave it only at the cost of losing some central part of their own being .....30

To the extent that we do not contribute to and partake of the language, culture, and tradition of our neighbors, that is, to the extent society "fails," we become "mad first to [others] and then to [ourselves]."31 We lose both the ability to understand and the ability to be understood. ${ }^{\mathbf{2}}$

so Grey, supra note 7 , at 895 .

${ }^{31}$ R. UNGER, supra note 8 , at 215 . Hannah Arendt has described the relationship of speech to meaning thus:

[W] hatever men do or know or experience can make sense only to the extent that it can be spoken about. . . . Men in the plural, that is, men in so far as they live and move and act in this world, can experience meaningfulness only because they can talk with and make sense to each other and to themselves.

H. ARENDT, supra note 16 , at 4.

32 In 1972, a flood wiped out the closely knit communities lining Buffalo Creek Hollow in West Virginia. At the request of Arnold \& Porter, the law firm representing the survivors of these communities, sociologist Kai Erikson documented the devastation caused by what he calls the "loss of communality" that followed the flood. See K. ERIkson, Everything in its Path: Destruction of Community in the BufFalo CReEK Flood 186-245 (1976). Most of the survivors were placed among strangers in trailer camps set up by the Department of Housing and Urban Development. Id. at 46-47. Although the camps did supply much-needed shelter, they also "served to stabilize one of the worst forms of disorganization resulting from the disaster by catching people in a moment of extreme dislocation and freezing them there in a kind of holding pattern." Id. at 47. The words of the people of Buffalo Creek make plain what can be entailed in the loss of community:

Well, I just don't feel like the same person. I feel like I live in a different world. I don't have no home no more. ... . [S]ometimes I just wonder if I'm a human being. I just feel like I don't have no friends in the world, nobody cares for me.

Id. at 214.

[I]t seemed like every time I tried to remember anything in my past, it bothered me tremendously-because the flood in its own way destroyed my past in the mental sense. I knew everybody in the area. That's where I lived, and that's what I called home. And I can't go back there anymore, I can't even think of it. I have no past.

Id.

I feel that the disaster has affected almost everyone on Buffalo Creek 
Conversely, the more society succeeds by "enhanc[ing] the continuity of a culture ... [and] increas[ing] a sense of connection in time and space,"ss the more we may realize the capacities of our species. ${ }^{34}$

To be a part of a community one must feel "at home" there. One must have a sense of attachment, both emotional and physical. It is important to

"recognize the centrality of [a] fixed place in the psychological architecture of traditional man. This centrality is reflected in our culture in innumerable ways. . . . The very word 'rootedness' to which we pay so much attention . . . is taken to mean a fixed place, a permanently anchored 'home' . . . one's link with both nature and the past."ss

Today, the home serves as a link not with nature but rather with the social order; it is a link that is both integrative and individuating. The home is integrative in that it places one physically in a social context, the locus from which one's engagement with others emanates. The home is individuating in that its boundary "excludes what is not wanted, or 'non-self' and incorporates what is psychically perceived as 'true self.' . . . [Housing] displays much of a person's interior life, including genuine feelings about identity." 36

Individuation does not imply isolation - the antithesis of community-but rather is a recognition that each individual is a unique part of her community, which, in turn, contributes to her uniqueness. The home identifies the individual's place within the community and often serves to communicate information about her identity to others; that is,

emotionally. People have no sense of belonging anywhere. There are no existing community identities left, only desolation and indecision.

Id.

Erikson explains the phenomenon thus:

People normally learn who they are and where they are by taking soundings from their fellows. As if employing a subtle form of radar, they probe other people in their immediate surround[ings] with looks and words and gestures, hoping to learn something about themselves from the return signals. But when there are no reliable objects out there to receive those exploratory probes, people have a hard time estimating where they stand in relation to the rest of the world. They come to feel that they are not whole persons because they have no confirmed place in the general drift of humanity.

Id. at 213-14.

ss K. LYNCH, Good CITY Form 116 (1st paperback ed. 1984) (originally published as K. LyNCH, A TheORY of Good GITY Form (1981)).

s4 See, e.g., R. UNGER, supra note 8, at 259-62.

ss N. NEWMARK \& P. ThOMPSON, supra note 27 , at 30-31 (quoting A. ToFFLER, FUTURE SHOCK 82 (1970)).

se Id. at 408. 
the home may be a symbol of the self, "rather than a defender of [the] self. The self-and-environment are seen in a state of mutual regard, rather than in a state of combat."

"Home" and "community" are not simply physical entities; they exist, perhaps above all, in our minds as

an expectancy of familiar things, the places, people, and the movements of time that in their way are ours. [They form] an accustomed pattern in which we are identified. The home and the home community are thus an essential kind of continuity in the fluid processes of living. It is a focal routine. Amid the centrifugal forces ... of the world, it is an organic nucleus. Here, and perhaps only here, do we find a continuity of values, a way or Tao ... . which alone gives wholeness to our lives. ${ }^{38}$

\section{Tenancy In Community}

In the preceding sections, I have described the way in which the community is inextricably linked to the identity of the individual and the sense in which one's home creates a link between oneself and others. This section will discuss some ways in which the status of "tenant" acts as an impediment to home and community.

\section{A. Secure Tenure and the Integrative Aspect of the Home}

As advocates of local empowerment have pointed out:

Without ownership of the house you live in or the turf you walk on, without some sense of security that you will not be evicted without reason, that the rent will not rise beyond your means to pay it, that the building won't be torn down ... no real [sense of] community can exist. ${ }^{39}$

This seems like a simple, commonsense proposition. If one's home, that which establishes one's "place" in the community, may be held only so long as it pleases another, one's connection to the community is in a state of constant doubt. ${ }^{40}$ Of neither her home nor her community can

${ }^{37}$ Cooper, The House as Symbol of Self, Design \& Env'T, Fall 1972, at 30, 33.

38 B. Brownell, The Human Community 77 (1950).

39 D. MORRIS \& K. Hess, supra note 29 , at 83.

40 This discussion is cast in terms of the common law. Common-law rules can be, and often are, altered by judicial or legislative action. See, e.g., Edwards v. Habib, 397 F.2d 687 (D.C. Cir. 1968) (holding that a landlord is not entitled to evict a tenant in retaliation for the tenant's reporting of code violations to housing authorities), cert. 
the tenant say "this is mine." She may have a right to be there for the moment, ${ }^{41}$ but that right will evaporate when her lease term expires: ${ }^{42}$ "Once the lease has ended the tenant is subject to the landlord's plenary and arbitrary power[,] for the landlord alone decides whether the tenant may renew the lease." ${ }^{33}$ The tenant's relationship to the community is thus marked by instability and transience.

The belief that tenants are less than full members of American society predates the founding of the Republic. ${ }^{44}$ Approximately onehalf of the American colonies limited the right to vote in colonial elections to the owners of freeholds; the remaining colonies imposed other forms of property- or tax-based restrictions. ${ }^{45}$ Indeed, the attitudes underlying these restrictions were well established among the nation's founders. James Madison argued that the "obvious and permanent division of every people is into the owners of the soil and the other inhabitants. In a certain sense the country may be said to belong to the former.' "46 Madison was not alone; John Adams, Daniel Webster, James Monroe, and John Marshall were among those with a similar view of extending the franchise to tenants:

[T] hey could not abandon a fundamental teaching of their fathers: that men without property lack the independence, interest, judgment, and virtue to be participating citizens of a free republic. They clung tenaciously ... to the inherited

denied, 393 U.S. 1016 (1969); N.J. STAT. ANN. § 2A:18-61.1 (West Supp. 1985) (providing that a landlord may terminate tenancy only for causes enumerated in the statute).

41 See, e.g., C. Moynihan, Introduction to the Law of Real Property 69 (1982) ("The distinctive feature of an estate for years is the right of the tenant to exclusive possession of a defined physical area for the duration of the specified term.") (citing Tips v. United States, 70 F.2d 525 (5th Cir. 1934); Willet v. Pilotte, 329 Mass. 610 , 109 N.E.2d 840 (1953)); R. SchoshiNSKI, supra note 1, at $\S 3: 1$ ("Having entered into a lease agreement, a tenant has an immediate right to enter and take possession of the leased premises upon the date fixed in the lease, and the landlord . . . is accordingly said to have an implied obligation not to withhold possession.") (footnote omitted).

12 See, e.g., R. Schoshinski, supra note 1 , at $\S 2: 13$ ("Normally, notice to terminate a periodic tenancy may be given for any reason whatsoever or for no reason at all.").

43 Quinn \& Phillips, The Legal History of Landlord-Tenant Relations, in Tenants and the URban Housing CRISIs 89, 100 (S. Burghardt ed. 1972).

${ }^{4} \mathrm{Cf}$. H. ARENDT, supra note 16, at 29-30 (In classical Greece, "without owning a house a man could not participate in the affairs of the world because he had no location in it which was properly his own.") (footnote omitted).

15 See C. Williamson, American Suffrage from Property to Democracy $1760-1860$, at $12-14(1960)$.

16 P. Larkin, Property in the Eighteenth Century 157-58 (1930) (quoting $3 \mathrm{M}$. Farrand, The Records of The Federal Convention of 1787, at 452 (1911)). 
doctrine of the "stake-in-society," which affirms that . . . voting should be the concern of those only who have "a common interest with, and an attachment to the community."

These concerns may have been heightened by the importance of local communities in eighteenth-century American politics. "The [colonial New England] town, not the individual, was the basic unit of political representation. Political decisions were made through 'discussion' and consensus rather than through interest-group conflict.".48 Colonial towns "exercised power as a group," and when "[t]he American Revolution broke out . . . the doctrine of the sovereignty of the people, which had been nurtured in the townships, took possession of the state." "so In the nineteenth century, however, local autonomy waned; "the world [was re-created] as one populated solely by the individual and the State."

The extension of the franchise to the propertyless paralleled this demise of local autonomy. ${ }^{52}$ Although there may not be a cause-andeffect relationship between these two phenomena, it is true that once the community is no longer an important political actor there is no justification for denying political status to the individual on the ground that her commitment to the community is questionable. Today, one ordinarily does not need to demonstrate a stake in the community in order to vote. ${ }^{\text {ss }}$ Nevertheless, it is still the case that "the American ideal

47 C. Rossiter, Conservatism in America 118 (2d ed. 1962), quoted in Heskin, Is a Tenant a Second Class Citizen?, in ReNT ConTrol: A SOURCE Book 95, 96 (J. Gilderbloom \& friends eds. 3d ed. 1981).

48 T. BENDER, supra note 27 , at 67 (footnote omitted).

49 Frug, The City as a Legal Concept, 93 HARv. L. Rev. 1059, 1098 (1980). Americans of the eighteenth century believed in "the possibility of checking human nature in its singularity by virtue of common bonds and mutual promises. The hope for man in his singularity lay in the fact that not man but men inhabit the earth and form a world between them." H. ARENDT, ON Revolution 174 (1963).

so 1 A. TocQueville, Democracy in America 58 (H. Reeve trans. 4th ed. New York 1841) (1st ed. n.p. 1838).

${ }^{51}$ Frug, supra note 49, at 1099. Professor Frug refers to "[t]he liberal effort to reallocate the powers of the medieval town to the individual and the state" as the source of the shift in political power from the community to the state. Id. at 1061 .

52 "[L]ocal autonomy remained largely intact" until the 1850's. Id. at 1108. Property requirements, at least for general elections, were abolished by 1860 . See Martin, The Supreme Court's Quest for Voter Equality in Bond Referenda, 28 BAYLOR L. REv. 25, 26 (1976).

The appropriation of localized power can itself be criticized as being based on liberal individualism's insistence on prioritizing the individual over the community. Professor Frug argues for a return of power to cities as a means to achieve "what Hannah Arendt has called the need for 'public freedom'- the ability to participate actively in the basic societal decisions that affect one's life." Frug, supra note 49, at 1068 (footnote omitted) (citing H. ARENDT, supra note 49, at 114-20).

Bs Property-based suffrage for general elections had been abolished by 1860 . See 
of homeownership is actually the ideal of perfected citizenship." Just twenty years ago, Justice Harlan, arguing that it was improper for the Court to adopt "current egalitarian notions of how a modern democracy should be organized" and to declare "all others to be irrational and invidious," "'ss noted that

it was probably accepted as sound political theory by a large percentage of Americans through most of our history, that people with some property have a deeper stake in community affairs, and are consequently more responsible, more educated, more knowledgeable, more worthy of confidence, than those without means, and that the community and $\mathrm{Na}$ tion would be better managed if the franchise were restricted to such citizens. ${ }^{\text {s6 }}$

Just four years ago, Stanford law professor Robert Ellickson claimed that "the intensity of a voter's interest in a community matter is likely to be positively correlated with the voter's economic stake in the community," a "rough approximation" of which "is the value of [her] interests in real property located within community boundaries." Es Ellickson argued that voting based on unit ownership, rather than residency, represents a "surer route to allocative efficiency"so and

Martin, supra note 52, at 26. After establishing the "one person, one vote" requirement in such cases as Wesberry v. Sanders, 376 U.S. 1 (1964) (congressional elections), Reynolds v. Sims, 377 U.S. 533 (1964) (state elections), Avery v. Midland County, 390 U.S. 474 (1968) (local elections), and Hadley v. Junior College District, 397 U.S. 50 (1970) (school district elections of educational trustees), the Supreme Court invalidated, on equal protection grounds, the restriction of the franchise to property-holding taxpayers in elections dealing with the issuance of municipal utility revenue bonds, see Cipriano v. City of Houma, 395 U.S. 701 (1969), and general obligation bonds, see Pheonix v. Kolodziejski, 399 U.S. 204 (1970). But see Ball v. James, 451 U.S. 355 (1981) (upholding water district election in which the franchise was limited to area landowners).

a C. Perin, Everything in Its Place: Social Order and Land Use in AMERICA 76 (1977).

S6 Harper v. Virginia Bd. of Elections, 383 U.S. 663, 686 (1966) (Harlan, J., dissenting) (arguing that the equal protection clause is not violated by conditioning the franchise on the payment of a poll tax).

${ }_{88} I d$. at 685 (footnote omitted).

87 Ellickson, Cities and Homeowners Associations, 130 U. PA. L. REv. 1519, 1544 (1982).

${ }^{88} I d$. at 1540 .

69 Id. at 1544; see also id. at 1539 (Members of an organization "would want to devise a voting system that would tend to lead to the adoption of policies that met (at least) the Kaldor-Hicks criterion for efficiency. This concern will be referred to as the goal of 'allocative efficiency." ") (footnote omitted); id. at $1531 \mathrm{n} .47$ ("A policy meets the Kaldor-Hicks criterion-'potential Pareto-superiority'-when the gainers gain more than the losers lose.").

Professor Ellickson recognizes that tenants do have a property interest in their 
that the Supreme Court should overrule its decisions that require one vote per resident in local elections because they prevent "subnational governments whose members weigh . . competing interests [allocative efficiency, administrative efficiency, progressive redistribution, and participation] differently than the Court weighs them from experimenting with other mechanisms for community decisionmaking." 60

Disdain for the transience of rental tenure appears in Congressional debates on housing legislation ${ }^{61}$ and in the beliefs of Americans who, when asked for their views on tenants, gave the following responses:

Renters are nonpermanent, renters have different motivations in terms of maintaining their units, in terms of commitment to community, in terms of involvement in community. ${ }^{62}$

It may be that there is this sort of feeling usually on the part of owners that people who rent are transient and I guess less culturally rooted and able to care for their property or just different .....$^{6 s}$

$[\mathrm{H}]$ omeowners ... just don't consider the apartment dweller as being truly indigenous to the neighborhood. . . . They have a very proprietary attitude about the neighborhood. ${ }^{64}$

The sense that a tenant is not really part of her community has encouraged a national housing policy dedicated to fostering single-family homeownership despite the fact that apartment living may be a superior housing form in modern society. ${ }^{65}$ Carla Hills, former Secretary of Housing and Urban Development, explained why she believed that

leases and that the value of that interest is a function of community policy. See id. at 1552. Rent and eviction controls increase the value of the lease and so, according to Ellickson, increase tenants' interests in community policy. See id. Limiting voting rights based on economic interest would thus create a Catch-22 for tenants who are not already protected by rent and eviction controls: because they have no economic stake in the community they are deprived of the vote, and because they are deprived of the vote they cannot pass referendums or elect candidates who would enact legislation giving them an economic stake in the community.

${ }^{60}$ Id. at 1559-60.

61 See G. Sternlieb \& J. Hughes, The Future of Rental Housing 2

62 C. PERIN, supra note 54, at 38.

63 Id. at 37.

B4 Id.

68 See Marcuse, The Ideologies of Ownership and Property Rights, in Housing Form and Public Policy in the United States 39, 41 (R. Plunz ed. 1980). 
the dream of homeownership should not be allowed to die:

"The family who owns its own home ... has an incentive to take an active role in the decisions which shape its ... community.... Those same family members as rental tenants might still classify as "good neighbors," but other than social pressure, they have no permanent incentive to be such. . . .

Homeownership provides a sense of identity, of roots and of security, which is the stuff from which neighborhoods are made and which protect against social alienation." ${ }^{\prime \prime 8}$

The views expressed above reflect the notion that one must hold permanent title to a piece of the community to be a true member. Under current law, the homeowner may, of course, lose her home if she fails to make required mortgage payments or if the state claims her home by eminent domain, but, as a general rule, her presence in her home and in the community is a matter of personal choice and does not depend on the arbitrary decisions of another individual. If the tenant were similarly secure in her tenure, if the property she rented were in this sense "hers," her status in the community might change considerably. Unlike tenants living under the common law, this tenant cannot be ejected from her home. With this security she can see herself as, be seen by others as, and in fact become a true member of her community.

\section{B. Freedom of Use and the Individuating Aspect of the Home}

The individuating function of the home-the aspect that promotes individual uniqueness-serves the individual's needs for both autonomy and community. As a sanctuary for realization of selfhood, ${ }^{67}$ the home is a place of freedom to be oneself as well as a means by which to express oneself to, and thus become known by, the community. Traditional landlord-tenant law permits the landlord such extensive control over her property that a person seeking to rent from the landlord may be excluded from the property entirely or may be admitted only on terms that prevent her from being "herself."

Bo C. PERIN, supra note 54, at 78 (quoting C. Hills, Remarks Before the American Bar Association (Aug. 13, 1975)).

67 See Radin, supra note 16, at 992 . In support of a "personhood" right to property; Professor Radin argues that "an individual needs some control over resources in the external environment" in order "to achieve proper self-development-to be a person." Id. at 957 . The right to a home, in particular, should be recognized because the "home . . . is the scene of one's history and future . . . [and] one embodies or constitutes oneself there." Id. at 992. 
Under common law, the landlord can select her tenants using whatever criteria, however arbitrary and unreasonable, she desired. ${ }^{68}$ Civil rights legislation has, in theory, restricted this traditional prerogative; ${ }^{69}$ nonetheless, any ground for discrimination not disallowed by statute is legally valid. Prospective tenants may thus be excluded based on characteristics such as parenthood, ${ }^{70}$ profession, ${ }^{71}$ pet ownership, ${ }^{72}$ marital status, ${ }^{73}$ and, presumably, hair color. While courts and com-

${ }^{68}$ See $\mathrm{R}$. SchoshINSKI, supra note 1 , at $\S 11: 1$; Rabin, supra note 2 , at 531 .

69 Federal fair housing legislation, see, e.g., 42 U.S.C. § $3601-3619$ (1982), prohibits discrimination by landlords on the basis of race, color, religion, national origin, or sex. See id. $\S 3604(a)$. Units in owner-occupied buildings and most single-family dwellings, however, are excluded from coverage. See id. § 3603. The California Supreme Court has interpreted a state antidiscrimination statute as prohibiting any "arbitrary" discrimination, see In re Cox, 3 Cal. 3d 205, 216, 474 P.2d 992, 999, 90 Cal. Rptr. 24, 31 (1970) (construing the Unruh Civil Rights Act, Cal. Grv. Cone $\S 51$ (West 1982)), and used this interpretation to prohibit discrimination in rental housing against tenants with children, see Marina Point, Ltd. v. Wolfson, 30 Cal. 3d 721, 741, 640 P.2d 115, 127, 180 Cal. Rptr. 496, 509 (en banc), cert. denied, 459 U.S. 858 (1982), and against homosexuals, see Hubert v. Williams, 133 Cal. App. 3d Supp. 1, 4, 184 Cal. Rptr. 161, 163 (App. Dep't Super. Ct. 1982).

${ }^{70}$ See R. Schoshinski, supra note 1 , at $\S 11: 12$. But cf. Halet v. Wend Inv. Co., 672 F.2d 1305, 1309-11 (9th Cir. 1982) (Upon a finding of "state action" and a "genuinely significant deprivation" of the right of family members to live together, a court may find that an adults-only rental policy violates constitutional guarantees of due process and equal protection.). In Halet, a local government (Los Angeles County) was heavily involved in the development and management of the apartment complex at which the adults-only policy was established; in many cases, prospective tenants will be unable to demonstrate the level of state involvement necessary to meet the state action requirement of the fourteenth amendment. See, e.g., Langley v. Monumental Corp., 496 F. Supp. 1144, 1147-51 (D. Md. 1980) (refusing to find state action in a landlord's adults-only rental policy even though the policy was sanctioned by explicit provisions of the county's housing discrimination ordinance).

${ }^{71}$ See, e.g., Kramarsky v. Stahl Management Co., 92 Misc. 2d 1030, 1032, 401 N.Y.S.2d 943, 945 (Sup. Ct. 1977) (upholding a landlord's refusal to rent to a lawyer and stating that "[a]bsent a supervening statutory proscription, a landlord is free to do what he wishes with his property, and to rent or not to rent it to any given person at his whim").

${ }_{72}$ See, e.g., Terhune Courts v. Sgambati, 163 N.J. Super. 218, 224, 394 A.2d 416, 418 (Bergen County Ct. 1978) (upholding a landlord's right to exclude pets), affd mem., 170 N.J. Super. 477, 406 A.2d 1330 (App. Div. 1979), cert. denied, 84 N.J. 418, 420 A.2d 331 (1980). But of. Young v. Savinon, 201 N.J. Super. 1, 492 A.2d 385 (App. Div. 1985) (holding that, in light of expert psychological testimony about the importance of the tenants' pet dogs to the tenants' mental and physical health, a change in the tenants' lease terms to prohibit pets was forbidden by a state statute permitting only "reasonable" changes in existing leases).

73 Despite statutory provisions prohibiting discrimination based on marital status, the New York Court of Appeals recently upheld a lease covenant prohibiting anyone not a tenant and not part of the tenant's "immediate family" from occupying the tenant's apartment. See Hudson View Properties v. Weiss, 59 N.Y.2d 733, 735, 450 N.E.2d 234, 235, 463 N.Y.S.2d 428, 429 (1983). According to the court, "Whether or not [the tenant's lover] could by marriage or otherwise become a part of her immediate family is not an issue. The landlord reserved the right . . . to restrict the occupants and the tenant agreed to this restriction." Id. Notwithstanding the court's unwillingness 
mentators have in some instances attempted to justify such discrimination as protecting the interests of other tenants, ${ }^{74}$ such power primarily furthers the self-interest of the individual in whose hands the power rests-the landlord. ${ }^{75}$ The effect of this grant of power is to deny those tenants who do not meet a landlord's particularized criteria for a "good tenant" the ability to choose their own homes. For some tenants-parents and pet owners, for example-this may mean exclusion from most of the housing in a given area. ${ }^{76}$ The tenant subject to such discrimination may be able to secure some house or apartment from a more lenient landlord, but it undoubtedly will not be the one that she would have chosen absent the discrimination. A tenant's very access to a community may therefore be limited by the power of landlords.

Once a landlord has agreed to rent to a tenant, the tenant acquires a right to possession for a specific period of time, but the landlord may exercise considerable control over the tenant's life while she is in possession. "[T]he landlord is free to attach whatever restrictions [she] wishes to the leasing of [her] property, and if clearly stated and not illegal or unconscionable, they are fully enforceable."

to characterize this treatment as discrimination under state and municipal law, it appears that this tenant was denied the right to live with a man solely because she had chosen not to marry him.

The clause at issue in Weiss-restricting occupancy to the tenant and "immediate family"-was subsequently rendered unenforceable by an enactment of the New York state legislature. See R. Schoshinski, supra note 1, at § 5:8 n.14 (citing the New York Omnibus Housing Act of 1983, § 64, N.Y. REAL PROP. LAw § 235-f (McKinney Supp. 1986)).

${ }^{74}$ See, e.g., Terhune Courts v. Sgambati, 163 N.J. Super. 218, 223, 394 A.2d 416, 418 (Bergen County Ct. 1978) ("Preventing a landlord who has allowed pets in the past from prohibiting them in the future would not be in the best interests of the tenants as a whole . ..."), affd mem., 170 N.J. Super. 477, 406 A.2d 1330 (App. Div. 1979), cert. denied, 84 N.J. 418, 420 A.2d 331 (1980), criticized on other grounds, Young v. Savinon, 201 N.J. Super. 1, 6-7, 492 A.2d 385, 388 (App. Div. 1985); Note, Why Johnny Can't Rent-An Examination of Laws Prohibiting Discrimination Against Families in Rental Housing, 94 HARV. L. REv. 1829, 1839 (1981) ("Restrictions on child discrimination also infringe the interests of renters who desire to live apart from children.").

${ }_{75} \mathrm{My}$ focus is on the relationship between tenant and landlord; I do not address whether or to what extent the tenants themselves, acting as a community, may impose conditions on the selection of new tenants. This problem in community theory, of little significance in a world populated only by the individual and the state, becomes increasingly important to the extent that political power is vested in local communities. $C f$. Frug, supra note 49, at 1080-120 (describing an earlier decline in the political power of local communities). In any case, whatever exclusionary power a community does hold does not belong in the hands of one individual-the landlord-who cannot claim authority to act on behalf of a group of which she may not even be a member.

78 See, e.g., Note, supra note 74, at 1829 ("Families searching for rental housing often find more than one-half of the vacancies closed to them; exclusion rates as high as $71 \%$ are not unknown.") (footnote omitted).

77 R. Schoshinski, supra note 1 , at $\S 5: 6$ (footnote omitted). Restrictive cove- 
lation of a specific lease provision may be forced from her home or required to conform to the lease. ${ }^{78}$

Substantial control by the landlord denies the tenant full use of her home in two respects. First, she can be prevented from living with those (people and pets) with whom she would like to live. For example, a lease that states "dwelling to be occupied by lessees only, no one in addition or instead"79 may be used to evict or enjoin a tenant in possession who wishes to live with a friend, lover, spouse, or children who were not lessees when the lease agreement was signed. A "no pets" clause will have a similar effect. Thus the tenant's possession is protected only so long as she lives with those her landlord deems acceptable. Such control of personal association by one individual over another is sharply at odds with the notion of home as the place where legitimate authority comes from within, at most subject to limit by the laws of a democracy, but certainly not subject to the rule of a dictator.

Restrictive lease covenants also prevent the tenant from truly having a home by limiting the way in which the rental unit may be used. For example, a lease that prohibits "any alterations, improvements, or additions to the demised premises" her unit as it was when she moved in. She can neither remove orange carpeting that she finds distasteful, nor install orange carpeting that most would agree is repulsive but that she happens to adore. As community development expert Franklin Becker has noted:

Ironically, we take a kind of schizophrenic attitude toward multifamily housing: we encourage people . . . to "improve" single-family houses . . . and yet we actively discourage the same activities in apartment residents. We seem to assume that each new occupant of an apartment wants it returned to its original condition. People want to find a new residence clean and well maintained, but we know of no evi-

nants will, however, be construed narrowly. See, e.g., St. Louis Union Trust Co. v. Tipton Elec. Co., 636 S.W.2d 357, 359 (Mo. Ct. App. 1982) (holding that a covenant prohibiting the tenant from making an appliance store the "principal use" of the property was not breached even though appliances constituted one-third of the tenant's inventory).

78 See R. SchoshINSKI, supra note 1 , at $\S 5: 9$ ("An action at law for damages, injunctive relief, and termination of a lease pursuant to a forfeiture clause are among the remedies available to the landlord for his tenant's breach of a restrictive use covenant.").

${ }^{79}$ This clause, which is a part of the author's lease, was added to a form lease agreement, Uniform Lease No. 50 (printed by John C. Clark Co., Philadelphia, June 1970), by the author's landlord. The author's lease is on file with the University of Pennsylvania Law Review.

so Uniform Lease No. 50, supra note 79. 
dence indicating that it should look exactly like all other apartments. $^{81}$

Presumably what Becker finds "schizophrenic" is that residences are treated differently depending on the tenure status of the resident-after all, one's home is one's home. Unfortunately, this is not at all a self-evident proposition; it is generally understood that one's home is not really one's home if it is rented. Becker, however, does not see the world through the eyes of the common law; rather, he focuses on the lives of the people who live under it. Because we are a territorial species, and it is the home that defines our territory, restrictions on the way we can use and personalize our homes conflict "with implicit norms about what an individual can do in a personal or group territory." nent of territory is the individual's or group's freedom to control the activities and determine appropriate behavior within a specific spatial area." which she can exclude others, for she must be willing to share control with her landlord.

Without the freedom to shape her environment, the tenant is deprived of a means of actualizing and communicating her identity: "Personalization reinforces the occupant's own sense of identity, as well as expresses it to others, and it is a way of demonstrating to others that the space is occupied by someone in particular." 84 The communicative aspect of personalization, particularly of the exterior of a building, "sets the stage for interaction," and 'connectedness' among . . . neighbors . . . [and] allow[s] residents to get to know each other and break down some of their unfounded stereotypes .... ."86 Removing the landlord's ability to exercise dominion over the tenant's environment brings the rental unit in line with our conceptions of the home. In some cases the effect might be purely psychological: a tenant may not actually want to paint her walls gray with a mauve trim, but knowing that no one could stop her from doing so is in itself an important element of what it means to have a home. ${ }^{87}$

81 F. Becker, Housing Messages 61-64 (1977).

82 Id. at 55 .

83 Id.

${ }^{84} I d$. at 51.

8s Id.

${ }^{88}$ Id. at 58 (footnote omitted).

87 Cf. id. at 124 ("Having the opportunity to [paint an apartment's walls but not doing so] . . . diminishes the validity of an individual's complaint that he or she cannot live in a place that is unresponsive to his or her own preferences. The apartment's condition becomes a function of what the individual does."). 


\section{REDISTRIBUTING THE RIGHTS OF OWNERSHIP}

In Parts I and II of this Comment, I discussed the ways in which community is an essential part of each individual and argued that a denial of a place in the community is a denial of an aspect of the self. Then, in Part III, I argued that several incidents of residential tenancy-insecurity of tenure, arbitrary discrimination, and restrictive use covenants-create a condition under which tenants do not have a "home" and thus cannot have a place in, and connection to, the community. In this section, I examine various rights of ownership and suggest where those rights would fall were we to create a legal structure embracing the value of community membership for tenants.

In conducting this analysis, $I$ assume that the basic conditions of landlordism and tenancy - the exchange of living quarters for periodic payment-as well as a system of legally recognized private property rights, will continue. Although the wisdom of these conditions may be questioned, this Comment is intended to be not a utopian enterprise, but rather a practical analysis of existing structures. Given that the acquisition of a private home is beyond the means and perhaps the desires of many, ${ }^{88}$ the division of ownership rights between landlord and tenant may be the most reasonable way to maintain an adequate housing supply. I further assume that, since we do not want to discourage people from providing homes in the form of rental housing, those who do so should not be deprived by the law of a fair return on their investment. A "fair return" will be taken to mean the rate of return that makes the construction or maintenance of rental housing, given the alternative uses of capital, an economically sound investment. ${ }^{89}$

According to Blackstone, to own property is to have "that sole and despotic dominion which one man claims and exercises over the external things of the world, in total exclusion of the right of any other individual in the universe." 90 This meaning survives in ordinary usage

88 See infra note 129 (setting forth data on renter-occupied housing).

89 At least one statute that prohibits a landlord from removing occupied rental units from the housing market if she is getting a fair return on her investment has been found constitutional. See Nash v. City of Santa Monica, 37 Cal. 3d 97, 688 P.2d 894, 207 Cal. Rptr. 285 (1984) (en banc) (considering Santa Monica, Cal., Gity CharTER art. XVIII, $\S 1803(\mathrm{t})$ ), appeal dismissed, 105 S. Ct. 1740 (1985).

${ }^{90} 2 \mathrm{~W}$. BLackstone, Commentaries on the Laws of ENGland 2 (11th ed. London 1791) (1st ed. Oxford 1766). The law of landlord-tenant by definition cannot meet Blackstone's conception of property. Indeed, Lord Blackstone did recognize something akin to a bundle of rights in his writings on estates in land. See Kennedy, supra note 25, at 335-37. "Blackstone classified estates in land, 'first, with regard to the quantity of interest which the tenant has in the tenement; secondly, with regard to the time at which that quantity of interest is to be enjoyed; and thirdly, with regard to the number and connections of the tenants." 'Id. at 336 (quoting 2 W. BLACKSTONE, 
but not in the law. At least since 1499-the year in which tenants won the right to legal enforcement of their possessory interest in their leaseholds"1-landlords have not held their property with "sole and despotic dominion." Rather, the "unitary conception of ownership" described by Blackstone has been "fragment[ed] . . . into a . . . 'bundle of rights." Thus, a thing can be owned by more than one person, in which case it becomes necessary to focus on the particular limited rights each of the co-owners has with respect to the thing."92

The "bundle of rights" in rental property should be allocated according to the particular functions that the property serves for the landlord and tenant. ${ }^{93}$ In the case of the landlord, the property is generally

supra, at 103).

${ }^{91}$ See Lesar, Landlord and Tenant Reform, 35 N.Y.U. L. REv. 1279, 1279

${ }^{92}$ Grey, The Disintegration of Property, in Property: Nomos XXII 69, 69 (J. Pennock \& J. Chapman eds. 1980); see also Unger, The Critical Legal Studies Movement, 96 HARv. L. REv. 561, 596-97 (1983) ("As any civilian or common lawyer should have known from the start, what we call property is merely a collection of heterogeneous faculties. These faculties can be broken up and assigned to different entities.").

${ }^{\circ 3}$ The idea of grounding property rights in property function has been suggested by Professors Margaret Radin and C. Edwin Baker. Professor Radin describes a continuum from personal property to "fungible property." Radin, supra note 16, at 95960 . Fungible property is that which is held instrumentally and is "perfectly replaceable with other goods." Id. at 960 . Personal property is that which people feel is "almost a part of themselves," $i d$. at 959, the loss of which "causes pain that cannot be relieved by the object's replacement." Id. (footnote omitted). To Radin, a house is personal, see id., while an "apartment in the hands of a commercial landlord" is fungible. See id. at 960 . Because personal property is essential to human development, see supra note 67 , Radin proposes that personal property "be protected to some extent against invasion by government and against cancellation by conflicting fungible property claims of other people." Radin, supra note 16, at 1014-15.

Professor Baker describes six functions-(1) use-value, (2) welfare, (3) personhood, (4) protection, (5) allocative, and (6) sovereignty-protected by property rules. See Baker, Property and Its Relation to Constitutionally Protected Liberty, 134 U. PA. L. REV. (forthcoming Apr. 1986). He argues that "these functions implicate several different values; and that constitutional analysis does and should depend on which functions (and hence which values) the challenged governmental practice implicates." Id.

In Flagg Bros. v. Brooks, 436 U.S. 149 (1978), Justice Rehnquist applied the "bundle of rights" conception of property to a tenant's personal possessions, which, at the request of a marshal, had been placed in storage after the tenant's eviction from her apartment. See id. at 160 n.10. In doing so, Justice Rehnquist recognized that property "rights" are mere creations of the states:

[The tenant's property interest in the possessions that the warehouseman proposes to sell] is not a monolithic, abstract concept hovering in the legal stratosphere. It is a bundle of rights in personalty, the metes and bounds of which are determined by the decisional and statutory law of the State of New York. The validity of the property interest in these possessions . . . depends on New York law, and the manner in which that ... property interest ... may be lost or transferred to still another private person likewise depends on New York law. 
held for its exchange value, as a means of generating income; thus, her rights in the property should protect her economic interests. The tenant, on the other hand, holds the property as her home. Her rights should therefore protect her ability to have a home in the sense developed in the preceding sections. At times, of course, the landlord's and the tenant's interests will conflict. ${ }^{94}$ In such cases the tenant should prevail up to the point at which the landlord's reversionary interest will be harmed or her rate of return dips below the "fair" level.

Favoring the tenant's rights in her home over the landlord's rights to maximize her profit is justified on the ground that a denial of home is a denial of community membership, which in turn is a denial of a constitutive part of the self. In contrast, denial of excess profits denies a part of the self only to the extent that one is fetishistic with regard to money.

With the ground rules established, we may proceed with a suggested relegation of ownership rights in a rental unit. Lawrence Becker, building on the work of A.M. Honoré, ${ }^{95}$ has devised an analysis of the "elements of ownership" that he has found to be "an adequate tool for analyzing every description of ownership [he has] come across." Becker identifies eight rights in property - the rights (1) to possess, (2) to use, (3) to manage, (4) to receive the income from, (5) to destroy, (6) to modify, (7) to alienate, and (8) to transmit ${ }^{97}$-any one or more of which "can stand as a variety of legal ownership when . . . supplemented by some version of [a ninth right,] the right to security."98 Becker also lists four elements of ownership-(1) absence of term, (2) prohibition of harmful use, (3) liability to execution, and (4) residuary (reversionary) rules-that serve as limits on the rights listed above. ${ }^{99}$ What follows is a proposed redistribution of landlord-tenant rights us-

Id. If, as Rehnquist argues, the law can carve up and redistribute the rights in a mattress between a tenant and a warehouseman, certainly it can do the same with the bundle of rights in a rental unit.

84 There is, of course, another set of interests that may conflict: those of the various tenants in a building. One tenant's exercise of control over her environment-for example, the holding of rock concerts on her balcony-may deprive her neighbors of the enjoyment of their homes. Although tenant/tenant conflicts are not the subject of this essay, as a general matter tenants whose practices cause misery to those around them should be required to cease the offending practices or face eviction: the age-old proposition that one may not use one's property to harm another. See, e.g., Vaughan v. Menlove, 132 Eng. Rep. 490 (C.P. 1837).

${ }^{83}$ Honoré, Ownership, in OXFord EsSAYs in JuRISPRUdence 107 (A. Guest ed. 1961).

${ }_{96}$ Becker, The Moral Basis of Property Rights, in PROPERTY: Nomos XXII, supra note 92, at 190.

${ }^{97}$ See id. at 190-91.

98 Id. at 192 .

${ }^{98}$ See id. at 191 . 
ing a number of these elements of ownership: the first six of those listed above in addition to the right to security and the absence of term.

\section{The Right to Possess}

The right to possess is defined as the right to "exclusive physical control of the thing." 100 Physical control, here the ability to exclude others, including the landlord, is an essential aspect of the home and thus rests with the tenant. This right is subject to the landlord's right to evict or enjoin the tenant for statutorily established "just cause," which would consist of failing to pay rent, committing waste, permitting a nuisance, or refusing the landlord reasonable access to make repairs or to show the premises to prospective purchasers or tenants. ${ }^{102}$ As such, the right to possess is analogous to the common law's "covenant of quiet enjoyment," which protects the tenant's use and possession of the premises against the landlord and all others claiming title. ${ }^{103}$ The tenant's possessory interest is thus protected up to the point at which it would unreasonably interfere with the landlord's economic interests and legal duties. ${ }^{104}$

\section{The Right to Use}

The right to use is defined as the right "to personal enjoyment of the benefits of the thing (other than those of management and income)."105 Clearly the benefits from use of the rental unit lie in the unit's home-providing function. Therefore, unless the landlord herself desires to use the unit as a home, there is no conflict of interests, and the right to use is the tenant's alone.

"Just cause" eviction statutes often permit eviction when the landlord wishes either to occupy the apartment herself or to have a member of her family do so. ${ }^{106}$ If, however, our concern is for protecting peo-

$100 \mathrm{Id}$. at 190.

101 For examples of existing "just cause" eviction statutes, see, for example, N.J. Stat. ANN. § 2A:18-61.1 (West Supp. 1985); Santa Monica, Cal., Gharter art. XVIII $\S 1806$. See also R. SchoshINSKI, supra note 1 , at $\S 7: 10$ (discussing state court interpretations of state and local eviction control measures).

102 See, e.g., N.J. STat. AnN. \& 2A:18-61.1(a)-(c) (West Supp. 1985); Santa Monica, Cal., Charter art. XVIII $\S 1806(\mathrm{a})$, (c), (f).

103 See R. SchoshINSRI, supra note 1 , at $\S 3: 3$. An express covenant may, however, take priority over the covenant of quiet enjoyment. See id.

104 For example, the landlord may seek access to an apartment in order to repair heating equipment or otherwise maintain the habitability of the premises. See id. $\S 3: 30$ (discussing statutory requirements that the landlord maintain rental units in a habitable condition).

105 Becker, supra note 96, at 190.

108 See, e.g., N.J. STAT. ANN. § 2A:18-61.1(3) (West Supp. 1985) (permitting 
ple's interests in their homes and communities, we should order existing interests above those manifest only in intent. If denying the landlord the right to move into a unit she "owns" seems unjust, it is because we are viewing the housing unit in terms of absolute ownership. Once the property in question is disaggregated into elements of function and correlative rights, it is possible to see this situation as the landlord's attempt to acquire a new use for the property. To do this she must extinguish an existing right and substitute her own. Favoring the tenant's current use right over the landlord's is both just and capable of surviving constitutional scrutiny by the courts. ${ }^{107}$

\section{The Right to Manage}

The right to manage is defined as the right "to decide how and by whom a thing shall be used." 108 In the first instance, the landlord makes the decision "how the thing shall be used" by offering to rent the unit as a residence; once she has taken this step, further decisions about how to use the unit as a home are for the tenant. The landlord may interfere only to protect her reversionary or economic interests.

In Part III I described the problems of allowing the landlord the right to discriminate arbitrarily against prospective tenants. In deciding who should use the property, a landlord's selection criteria should be based only on those factors that may affect her economic interests: the ability to pay rent and the likelihood that a potential tenant will commit waste or create a nuisance. ${ }^{109}$ Once the tenant has moved in, the

eviction for owner occupation in buildings with three or fewer units); SANTA MoNICA, GaL., CharTer art. XVIII $\S 1086(\mathrm{~h})$.

${ }_{107}$ See, e.g., Nash v. Gity of Santa Monica, 688 P.2d 894, 896-97 \& n.3, 207 Cal. Rptr. 285, 287-88 \& n.3 (1984) (en banc) (upholding against various constitutional challenges an ordinance that prohibits a landlord from converting or demolishing rental units unless she first obtains a permit by showing, among other things, that she cannot make " "a fair return on investment" ") (quoting SANTA MoNICA, CAL., CHARTER art. XVIII, \& 1803(t)), appeal dismissed, 105 S. Ct. 1740 (1985); Flynn v. City of Cambridge, 383 Mass. 152, 159-61, 418 N.E.2d 335, 339-40 (1981) (holding that a condominium conversion ordinance prohibiting the eviction of tenants living in controlled rental housing was not an unconstitutional taking of property); Puttrich v. Smith, 170 N.J. Super. 572, 575, 407 A.2d 842, 843-44 (App. Div. 1979) (finding that a statute prohibiting the landlord from evicting tenants in order to expand the landlord's business was not an unconstitutional taking of property but rather a reasonable exercise of police power); Stamboulos v. McKee, 134 N.J. Super. 567, 572-73, 342 A.2d 529, 532 (App. Div. 1975) (The legislature may decide that the owner's right to use her property must yield to the tenant's interest in keeping her home.); see also infra note 121 (discussing the Nash case in greater detail).

${ }^{108}$ Becker, supra note 96, at 190.

109 For landlords who occupy a unit in their rental property, the building functions as their home and not merely as a source of income. These landlords could be allowed more leeway in selecting tenants. 
landlord's right to exclude others from the apartment should be limited to the grounds on which she could exclude the original tenant. The first tenant should otherwise be free to invite anyone to share her home, provided that the number of people in the unit does not rise to the level of a health or safety code violation. ${ }^{110}$

The most frequently excluded "tenants" are children and pets. ${ }^{111}$ It is true that both can be noisy and perhaps more destructive than human adults; it is also true, however, that both can be a significant part of the lives of people who have them. ${ }^{112}$ Absent a specific showing

110 See, e.g., Philadelphia, Pa., Code § 7-204 (1983) (requiring compliance with minimum standards for space per person, use, and location).

113 See R. Schoshinski, supra note 1 , at \& 5:8.

112 Discrimination against families with children is currently prohibited in some jurisdictions. See R. SchoshiNSKI, supra note 1, at $\S 11: 12$; Note, supra note 74, at 1829 n.4 (collecting statutes); Note, Housing Discrimination Against Children: The Legal Status of a Growing Social Problem, 16 J. FAM. L. 559, 565-87 (1978).

A New Jersey Superior Court recently recognized just how important pets can be to their owners. In Young v. Savinon, 201 N.J. Super. 1, 492 A.2d 385 (App. Div. 1985), a landlord who had purchased an apartment building after the dog-owning tenants were in residence attempted to evict several tenants for not conforming to a "no-pets" provision in a renewal lease. The previous landlord, who had executed the original leases, had permitted the offending German shepard, Scottish terrier, and Chihuahua to reside in the building. The plaintiff-landlord knew that pets were allowed when he bought the building, but he was afraid of dogs and "admit[ted] purchasing the premises with the intention of forcing the tenants either to get rid of their pets or move." Id. at 5, 492 A.2d at 387.

New Jersey, by statute, requires landlords to "be 'reasonable' in their relations with their tenants insofar as placing restrictions upon a tenant's activities." Id. at 6, 492 A.2d at 388 (quoting N.J. STAT. ANN. § 2A:18-61.1 (West Supp. 1985)). Based in large part on expert testimony and the former landlord's policy, the court found the "no-pets" provision unreasonable and refused to enforce it. See id. at 9, 492 A.2d at 390. The testimony of Dr. Aaron Katcher, a University of Pennsylvania psychologist specializing in the influence of pets on the well-being of their owners, established

that the loss of ... pets to people such as defendants would cause significant health problems . . . . Defendants could be expected to suffer grief and depression as great as that suffered at the loss of a family member and, in addition, suffer from a sense of guilt and loss of self-esteem. On a positive note, the witness testified to studies showing that the presence of a pet lowers blood pressure, decreases anxiety, combats depression and generally increases the owner's health. In fact, the presence of pets generally lowers the rate of mortality. As to [the three defendants], Dr. Katcher testified that one would be increasingly unwilling to leave her home, another would suffer a worsening in her cardiovascular system and increased hypertension and the third would experience severe grief, especially since this woman would not only grieve for the loss of her dog but suffer a reawakened grief for the loss of her sister, the dog's former owner. He expected that if these women were forced to choose between giving up their pets or moving, they would feel forced to move.

Id. at 5-6, 492 A.2d at 387-88 (emphasis added); see also Fox, Relationships Between the Human and Nonhuman Animals, in INTERRELATIONS BETWEen PEOPLE aND PETs 29-35 (B. Fogle ed. 1981). According to Fox:

There are many subtle values and needs associated with pet ownership. 
that the child or pet in question is disruptive, dangerous, or destructive, neither should be barred from rental housing. In the case of some pets (for example, large dogs but not finches) or children between the ages of two and ten, the landlord could be allowed to require a supplemental damage deposit.

One might question whether others in a neighborhood or apartment building should be protected in their "right" to live in a pet-free or child-free environment. The answer might be "yes" if the deprivation to pet owners and parents were less severe and the benefit to the other residents were more substantial. In the case of children, at least one court has recognized the social necessity of maintaining conditions under which procreation and child rearing are not burdened by selfish, discriminatory practices:

Attributed to W.G. Fields is a statement that, "anyone who hates children and dogs can't be all bad." We can certainly understand the motivation of some adults to seek the peace and quiet of a setting that is free from the rough and tumble commotion of exuberant youth. However, the right of an adult to enjoy such relative tranquillity is decidedly outweighed by society's vital and compelling interest in providing housing which fosters wholesome development of its children. As the [Galifornia] Supreme Court [has] observed ...., "[n]either statute nor interpretation of statute, however, sanctions the sacrifice of the well-being of children on the altar of a landlord's profit, or possibly some tenants' convenience."113

As long as we are a society of pet owners and child-havers, tenants of this description should not encounter discrimination in acquiring their homes.

Pets provide companionship for those lonely people who feel alienated from or dehumanized by society. They give a sense of family and community to countless numbers of elderly retired people and also to young couples who are childless. Pets are significant nonhuman companions and child substitutes for many. They are always accepting, and with the unconditional love that they can offer, they are beneficial for a person's emotional well-being.

Id. at 29-30. See generally Pet Animals and Society (R. Anderson ed. 1975) (collection of articles discussing the psychological relationship between people and their pets).

113 Schmidt v. Superior Court, 215 Cal. Rptr. 840, 848 (Ct. App.) (quoting Marina Point, Ltd. v. Wolfson, 30 Cal. 3d 721, 745, 640 P.2d 115, 129, 180 Cal. Rptr. 496, 511 (en banc), cert. denied, 459 U.S. 858 (1982)), review granted, 218 Cal. Rptr. 303 (1985). 


\section{The Right to Income}

The right to income is defined as the right "to the benefits derived from foregoing personal use of a thing, and allowing others to use it." "114 This definition encapsulates the core of the landlord's rights in the property. In most cases it will be the predominant right; if the tenant fails to pay her rent, she will lose all of her rights in the property. The right to income does, however, have limits. First, the landlord should, and in most jurisdictions does, ${ }^{115}$ have a duty to maintain the premises in a "habitable condition."116 When this warranty is breached, the tenant may, among other things, withhold some or all of her rent. ${ }^{117}$ Second, the rate of rent may be controlled to protect tenants in tight housing markets from being priced out of their homes. ${ }^{118}$ When the established rent is too low to permit the landlord a fair return, however, she may be entitled to an increase. ${ }^{119}$ Finally, where, in the absence of or despite rent control, an individual tenant will lose her home because she can no longer pay the rent, she should be entitled to a rent reduction to the fair rate of return.

In sum, the landlord should have a protected right to income, but upper limits may be imposed on the amount of income to be protected. Furthermore, the landlord must fulfill her legal obligations if she is to have an enforceable claim to that income. This arrangement both protects tenants from dislocation and promotes the continued existence of

114 Becker, supra note 96 , at 90.

115 See Glendon, supra note 2, at 529 (citing Cunningham, The New Implied and Statutory Warranties of Habitability in Residential Leases: From Contract to Status, 16 URB. L. ANN. 3 (1979)).

${ }_{116}$ Although today the duty to maintain premises in habitable condition is often required by statute, see supra note 98 , it originated in the courts. The leading warranty-of-habitability case is Javins v. First Nat'l Realty Corp., 428 F.2d 1071, 1080 \& n.49 (D.C. Cir.) (The requirement in the District of Columbia's housing code that landlords adequately maintain premises may not be waived; the common-law no-dutyto-repair rule was based on outdated factual assumptions about tenancy.), cert. denied, 400 U.S. 925 (1970).

There is no consensus on the scope of the warranty of habitability, see $R$. SchoshinSKI, supra note 1 , at $\S 3: 17$, but "[c]ourts generally find a breach . . . only when the premises are rendered truly unsafe, unsanitary, or unhabitable." Id. (footnote omitted).

117 See R. Schoshinski, supra note 1 , at $\S 3: 19$; $c$. Sterling v. Santa Monica Rent Control Bd., 214 Cal. Rptr. 71, 75-78 (Ct. App. 1985) (discussing the practice of reducing maximum rents under rent control to reflect decreases in the landlord's maintenance or other operating expenses).

${ }^{118}$ See Rabin, supra note 2, at 527 \& n.34 (In 1982, rents in over 200 cities were regulated.); see also Baar \& Keating, The Last Stand of Economic Substantive Due Process-The Housing Emergency Requirement for Rent Control, 7 URB. LAw. 447 (1975) (discussing the view that rent control provisions that are not enacted in response to an emergency housing shortage are unconstitutional).

110 See, e.g., Santa Monica, CaL., Charter art. XVIII $\S 1805$ (c). 
adequate levels of rental housing.

\section{The Right to Consume or Destroy}

The right to consume or destroy is the right "to annihilate the thing." ${ }^{120}$ In the case of rental units, neither landlord nor tenant should be able to exercise this right unilaterally. Clearly the tenant should not have this right; otherwise she could annihilate the landlord's reversionary interest. But neither should the landlord be able to annihilate the tenant's present interest, unless the landlord would otherwise be forced into bankruptcy. Prohibiting landlords from demolishing profitable buildings because they can increase their profits by putting the land to another use may be economically inefficient but is nevertheless justifiable as a variation of the function-change prohibition discussed above under the "right to use."121 Condominium conversion, insofar as it leads to the eviction of tenants, also can be seen as a form of destruction-the rental unit does cease to exist-and should be prohibited for the same reasons. ${ }^{122}$

\section{The Right to Modify}

The right to modify is defined as the right "to effect changes less extensive than annihilation."123 Modification covers what was described as personalization in Part III; the ability to effect changes in one's residence is part of being at home in one's home. The landlord's right to prevent modifications by the tenant should be limited to instances of

120 Becker, supra note 96, at 191.

121 The Supreme Court of California recently upheld a section of the Santa Monica City Charter that prevents a landlord from evicting tenants or demolishing most rental units without first obtaining a city permit. See Nash v. City of Santa Monica, 37 Cal. 3d 97, 688 P.2d 894, 207 Cal. Rptr. 285 (1984) (en banc) (upholding Santa Monica, Cal., Charter art. XVIII, § 1803(t)), appeal dismissed, $105 \mathrm{~S}$. Ct. 1740 (1985). The court based its decision on the following grounds: that the ordinance was not an unconstitutional taking of property; that there were ways for the landlord to minimize his involvement with the business of managing the building so that the ordinance did not impose an involuntary servitude on the landlord; that the landlord was, by his own admission, still getting a fair rate of return; and that the ordinance was reasonably related to the city's legitimate end of maintaining sufficient rental housing. See 37 Cal. 3d at 102-09, 688 P.2d at 898-903, 207 Cal. Rptr. at 289-94.

122 See, e.g., Griffin Dev. Co. v. City of Oxnard, 703 P.2d 339, 344-45, 217 Cal. Rptr. 1, 6-7 (1985) (en banc) (holding that a city's regulation of condominium conversions is a legitimate exercise of its police power and that the denial of a permit to convert apartments to condominiums is not a confiscatory taking of property); Flynn v. City of Cambridge, 383 Mass. 152, 159-61, 418 N.E.2d 335, 339-40 (1981) (holding that a condominium conversion ordinance prohibiting the eviction of tenants living in controlled rental housing was not an unconstitutional taking of property).

${ }^{123}$ Becker, supra note 96, at 191. 
waste $^{124}$ that actually decrease the value of the property. Thus, in contrast to the common law-which allowed the landlord to prohibit any modification whatsoever-the law of waste would be the only restriction on the tenant's creativity. The landlord's right to modify the premises without express agreement by the tenant would be limited to repairs necessary to maintain habitability.

\section{The Right to Security}

The right to security-defined as the right "to immunity from expropriation"125 - converts other rights into a form of legal ownership. Thus, a right to security in rental housing would require that the rights discussed above be established and enforceable under the law. This right would extend to both landlord and tenant to the extent necessary to create the condition of ownership in their respective rights; conflicts between these rights would be resolved when either landlord or tenant seeks enforcement.

\section{The Absence of Term}

Absence of term is "the indeterminate length of one's ownership rights."126 For both the landlord and tenant, the term may be conditioned on the satisfaction of obligations such as mortgage and rent payments, but in general the term should be indeterminate. ${ }^{\mathbf{1 2 7}}$ For landlords this is the status quo; for tenants it is an essential right if they are to be free to attach themselves to, and become members of, the community. Many tenants are currently granted indeterminate tenure by "just cause" eviction statutes; ${ }^{\mathbf{1 2 8}}$ such protection should be universal.

Were the law, within a system of indeterminate tenure, to protect tenants in their possession, use, management, and modification of rental units, tenants would have property rights in a home rather than in a temporary shelter.

124 "The law of waste may be defined as the proscription of conduct by a tenant which results in permanent damage, which reduces the value of the reversion or remainder, and which is not justified as a reasonable exercise of ownership under the terms ... of the instrument creating the estate in the tenant." $R$. ScHOSHINSKI, supra note 1 , at $\S 5: 22$ n.24.

125 Becker, supra note 96, at 191.

128 Id.

${ }^{127}$ People who, for example, rent their own homes to others, intending to live there again in the future, would be appropriately excepted from the general rule.

${ }^{128}$ See supra text accompanying notes 101-02 (discussing the limitations on the landlord's eviction rights under "just cause" eviction statutes). 


\section{CONCLUSION}

Over one-third of the housing in this country is renter-occupied. ${ }^{129}$ In many respects, those of us who are members of the significant segment of the population having the status of tenant are, by this very status, denied the full benefit of having a home both in the dwelling we occupy and in the community. As Professor Radin has argued, "[T]enants should be allowed to become attached to places and ... the legal system should encourage them to do so." developing this sense of attachment that tenants will be able to consider themselves true members of their communities. The exclusion of tenants, because of the essential role community plays in the identity of the individual, effectively denies part of what it means to be a person.

In recognizing the impossibility of considering what it means to be human without reference to the community, we can gain a perspective from which to criticize those aspects of the legal system that exclude individuals or groups from the community. From this criticism we can develop appropriate directions for legal change. For example, the exclusionary impact of the landlord-tenant relationship could be rectified by vesting in the tenant the elements of property ownership that protect the home-providing functions of a dwelling, while bestowing on the landlord the elements that protect the income-producing function. The legislative and judicial restructuring of landlord-tenant law experienced in recent decades has improved the status of many tenants; however, only when tenants are secure in those property rights that one must have in order to have a true home will they gain full membership in the community.

129 In $1980,36 \%$ of dwelling units in the United States were renter-occupied; housing inhabited by minorities (Blacks, Asian/Pacific Islanders, and persons of Spanish origin) was $55 \%$ rented. U.S. DEPARTMENT OF COMMERCE, BUREAU OF THE CENsus, 1980 Census of Population and Housing Supplementary Report: Provisional Estimate of Social, Economic, and Housing Characteristics, States and Selected Standard Metropolitan Statistical AReas 100 table H-4 (1982). California has an overall rental unit rate of $44.7 \%$ and a minority rate of $56 \%$, see id., while New York has an overall rate of $53 \%$ and a minority rate of $80 \%$. See id. at 105.

130 Radin, supra note 16 , at 994. 